\title{
Turbulência histórica e fertilidade intelectual: uma leitura política da historiografia de Marc Bloch e Lucien Febvre*
}

Guilherme Ribeiro**

Resumo: O objetivo deste trabalho é reconhecer a dimensão política presente na historiografia de Marc Bloch e Lucien Febvre. Por terem deslocado a história política e enfatizado a história econômica e social, seus trabalhos têm sido interpretados como se não abordassem questões políticas. O presente artigo pretende questionar essa leitura.

Palavras-chave: História. Historiografia. Política. Marc Bloch. Lucien Febvre.

\section{Introdução}

Ainda é possível acrescentar algo sobre a corrente historiográfica mais debatida e polemizada do século XX? Sim, é possível. Afinal, o passado está sempre em movimento, os primeiros Annales são constantemente evocados pelos historiadores em

\footnotetext{
* Este trabalho foi financiado pela Capes.

** Professor Adjunto do Instituto de Ciências da Sociedade e Desenvolvimento Regional da Universidade Federal Fluminense (UFF). E-mail: geofilos@ig.com.br.
} 
nossos dias e suas ideias ao redor dos métodos e técnicas de pesquisa afetaram não apenas a história mas as ciências sociais como um todo.

No intuito de compreender determinado fenômeno da história das ideias, três coisas nos parecem fundamentais: (1) o contexto histórico que o cerca e o constitui; (2) o debate político que o atravessa; (3) uma caracterização epistemológica geral. Revisando alguns dos estudiosos dos Annales, nota-se, em geral, que o terceiro tópico domina amplamente os demais (BOURDÉ; MARTIN, 1997; BURKE, 1997; CAIRE-JABINET, 2003; GURIÊVITCH, 2003; LE GOFF, 1990; NOIRIEL, 2005; POMIAN, 1997). Não são muitos os que aprofundam a relação dos primeiros Annales com o colonialismo, a Revolução de 1917, os movimentos sociais franceses e outros acontecimentos históricos que, postos em relevo, fariam emergir a postura política e a ideologia contidas na escrita histórica de Marc Bloch (1886-1944) e Lucien Febvre (1878-1956).

Não estamos sozinhos quando o assunto é um olhar crítico lançado aos estudiosos da corrente em questão. Revel (1979, p. 1361) é preciso quando assevera que a maior parte do que tem sido consagrado a ela advém da perspectiva criada pelos próprios Annales ao redor de si mesmos. Por sua vez, Burguière (1979) recusa uma leitura cujo encaminhamento sugere que os Annales respondiam a uma urgência epistemológica da época. Ao contrário: para ele, o movimento foi uma exceção histórica (BURGUIÈRE, 1979 , p. 1347). Sem meias palavras, o historiador espanhol Josep Fontana aponta o que qualifica como "literatura mitificadora" em torno dos Annales (FONTANA, 2004, p. 257). Ora, o que são as ideias quando desacompanhadas de historicidade e conteúdo político?

Situação exposta, as páginas que seguem ensejam problematizar alguns dos elementos teórico-metodológicos desenvolvidos por Bloch e Febvre no seio do processo histórico vivido pela França e pela Europa nas primeiras décadas do século passado e sua dimensão política. 


\section{O contexto histórico de formação dos Annales}

"Breve século XX": foi assim que Hobsbawm (1995) resumiu os cem anos precedentes, pois ele começara e terminara com uma guerra de origem essencialmente europeia (a de 1914-1918 e a dos Bálcãs na década de 1990). Ao mesmo tempo, o eminente marxista inglês também o via como a "Era dos Extremos", dadas suas profundas transformações de ordem econômica, política, social e cultural nos mais diferentes países e continentes. Pode-se destacar, pelo menos, três dessas mudanças: na demografia, onde um aumento sem precedentes da população veio na esteira da revolução econômica, originando mais trabalho e mais consumidores; no volume do comércio e da emigração, onde as trocas comerciais passaram a ter o globo como cenário e as pessoas não mais se restringiam a morar por toda a vida no local onde haviam nascido; e nas comunicações e transportes, com a construção das ferrovias, o desenvolvimento das técnicas hidroviária e aeroviária e a progressiva expansão do automóvel engendrando relações sociais absolutamente novas (HOBSBAWM, 1995).

A dinâmica do capitalismo, a industrialização e o liberalismo econômico foram, certamente, os grandes responsáveis pela criação de relações cada vez mais globais. Por conta deles, uma nítida divisão internacional do trabalho cindia o mundo em duas partes: de um lado, países produtores de mercadorias e, de outro, países fornecedores de matérias-primas de baixo valor agregado. Por conta deles, o imperativo de expansão dos mercados e dos lucros culminara no imperialismo, isto é, na conquista e partilha da África e da Ásia pelas potências europeias. Todavia, a unificação fragmentada então em curso, simultaneamente ao fato de proporcionar enormes benesses aos homens de negócios, também admitia a possibilidade de uma crise numa escala de amplitude fora dos padrões até então existentes.

Esta parece ser uma das especificidades do século em voga: o caráter global de seus fenômenos, o espraiamento veloz das informações, a ultrapassagem da escala local. Não se enquadram nessa ordem a Revolução Russa, a Primeira Guerra Mundial e a 
Crise de 29? Ironicamente, esses três acontecimentos são filhos de visões e representações de mundo provenientes do século XIX: do marxismo e da vontade de construir de uma nova sociedade; do imperialismo e da necessidade de reorganizar o mapa geopolítico europeu; e do liberalismo apoiado no ideal abstrato da "mão invisível". Historicamente, eles são indícios de um abalo mais amplo: a crise da modernidade.

Como a França se insere nessa conjuntura? Segundo Maurice Agulhon (1990), naquele país o início do século XX é de prosperidade econômica e modernização tecnológica. Começava-se a desfrutar das descobertas científicas do final do século anterior, como a eletricidade e o motor de explosão, facilitando tanto a vida no lar quanto o trajeto de ida e volta ao trabalho. A sequência do investimento em educação pública e gratuita permitia o surgimento da grande imprensa e de jornais populares e provincianos. Liam-se romances em formato de folhetins, o teatro era comentado, descobria-se o cinema. $\mathrm{Na}$ política, permaneciam as disputas em torno da defesa dos ideais republicanos: novos atores sociais, como o movimento operário de esquerda (representado pela Seção Francesa da Internacional Trabalhista), entravam em cena, ao mesmo tempo em que reações de direita também se faziam presentes (L’Action Française de 1905). Provenientes da Revolução de 1789 e suas conquistas, tais ideais (a justiça e a ética, por exemplo) localizavam a França na dianteira do progresso, situando-a na posição de mandatária legítima da Alsácia-Lorena e de principal difusora de bens culturais e civilizacionais junto ao mundo colonial. Em defesa dos interesses franceses, em 1914 mesmo o patriotismo de esquerda (não a extrema-esquerda) aceitava a guerra, enquanto a lembrança de 1870-1871 era restrita aos mais velhos. Por sua vez, a história e a literatura se encarregavam de propagar o culto aos grandes homens e a imagem de retidão moral e valentia física como típicas do caráter francês. Contrário a esse estado de coisas, Jean Jaurès trava uma luta contra o colonialismo e a inaptidão da diplomacia francesa para impedir a guerra. Inspirado pelo socialismo humanista, combate o nacionalismo e apoia o internacionalismo, condescendente à ideia de que uma greve geral além-fronteira poderia deter os exércitos (AGULHON, 1990, p. 
205-254). A despeito de sua destacada atuação política e intelectual, naquela ocasião os esforços de Jaurès malograram...

Ainda de acordo com Agulhon (1990), a eclosão do conflito e suas principais etapas são bem conhecidas de todos - sobretudo dos franceses, para quem a Grande Guerra não foi 1939-1945, mas sim 1914-1918. O entusiasmo da vitória não dissimulava as perdas materiais e espirituais do confronto: regiões inteiras devastadas; quase um milhão e meio de mortos; número considerável de feridos e mutilados; produção enfraquecida; reservas financeiras debilitadas e endividamento junto aos antigos aliados (notadamente os americanos). Além disso, às dificuldades econômicas somavam-se os movimentos sociais, cada vez mais vinculados às esperanças revolucionárias da Europa central e oriental. De outro lado, porém, o preço do triunfo era considerável: a recuperação da Alsácia-Lorena e a ampliação dos territórios coloniais por conta das áreas retiradas dos alemães e dos turcos. No que concerne ao mapa europeu, a França anexaria provisoriamente a Sarre (rica em carvão) e ocuparia militarmente a Renânia até o Reno, além da garantia de assistência dos ingleses e americanos em caso de agressão germânica - algo difícil por causa das condições impostas pelo Tratado de Versalhes (1919) à Alemanha, tais como a total desmilitarização e o pagamento de reparações de guerra. Todavia, a segurança das fronteiras do Reno só seria obtida através dos acordos de Locarno em 1925, reunindo GrãBretanha, Itália, Bélgica, França e Alemanha.

No que tange à geopolítica mundial, após 1918 há uma aproximação com o Império Britânico e com os pujantes Estados Unidos. A maciça presença francesa na África e suas colônias na Ásia, América e algumas ilhas na Oceania garantiam uma série de benesses (exploração de recursos naturais e mão de obra nativa, controle estratégico de rotas, expansão do capital privado nacional, etc.), bem como uma posição de peso nas decisões referentes ao cenário internacional. Orgulhosos de seus domínios, os franceses organizam em Paris uma grande exposição colonial (1931). Ironicamente, seu tom ufanista e ideológico contrastaria, no mesmo ano, com a primeira insurreição anti-imperial na Indochina. Quatro anos antes, Voyage an Congo, de André Gide, havia denunciado 
os abusos das grandes companhias coloniais e, em 1925, o comunista Jacques Doriot enviara telegrama de apoio ao rebelde marroquino Abd el-Krim. Signos de uma descolonização que parecia inevitável.

No campo econômico, pouco a pouco a reconstrução vai assumindo espaço: no entreguerras, a produção de automóveis e aviões é surpreendente, e um relativo atraso industrial amenizou consideravelmente os efeitos da Crise de 29. Entretanto, o não pagamento da reparação de guerra pelos alemães e a suspensão de todos os saldos internacionais pela moratória Hoover durante um ano levariam a uma nova crise (1932). No campo demográfico, embora as cidades cresçam devagar, 1931 vê a população urbana ultrapassar a população rural. Nessa mesma data, imigrantes da África do Norte, Polônia, Espanha e Itália totalizavam 3 milhões de pessoas.

Enfim, um impacto significativo na política e na sociedade francesas estava em curso. Se é verdade que os comunistas já acusavam a prioridade à luta proletária internacional em detrimento do particularismo das questões nacionais, a Primeira Guerra Mundial foi o principal canal no sentido de uma alteração na forma de apresentar a história aos cidadãos. $\mathrm{O}$ nacionalismo pregado pelos manuais escolares republicanos não era mais o mesmo de outrora (AGULHON, 1990, p. 323-378). A história dos homens mostrava aos historiadores que o caminho a seguir deveria ser outro que o dos militares, tratados e batalhas. $\mathrm{O}$ que estava em jogo e precisava ser feito era a reconstrução econômica e social da nação.

É justamente no interior desse panorama que devemos estudar os primeiros Annales. A verdade é que eles praticavam a história de seu tempo, ou seja, uma história que atendia às demandas da sociedade francesa ciosa por um projeto de convergência e reestabelecimento nacional. Nesse caso, não há diferença entre os Annales, a geografia vidaliana, a sociologia durkheimiana e a escola metódica, pois, à sua maneira, cada uma dessas vertentes das ciências humanas propunha tanto a renovação de seus campos de conhecimento quanto alternativas político-sociais que atingiam em cheio os problemas da realidade francesa de então. $O$ fato de tais correntes estarem umbilicalmente ligadas ao nascimento dos 
Annales não é mera coincidência e tampouco pode ser visto apenas sob o viés epistemológico. Devemos interpretá-lo como uma convergência histórica entre projetos científicos gerados em meio à formação, tensão e consolidação dos Estados nacionais europeus durante os anos de 1871 e 1945. Afinal, o que representam temas como a interdisciplinaridade, a criação de projetos coletivos de pesquisa e a ênfase na história econômico-social em detrimento da história política, bem como as análises sobre "a estranha derrota" de 1940, o apoio à missão civilizatória do colonialismo e a defesa do Reno não como um rio alemão mas como um rio europeu, senão uma congregação de forças e uma concepção ampliada acerca do passado, presente e futuro da França? Sim, não se tratava mais de uma perspectiva chauvinista que via a história como um meio de acertar as contas com o passado e com a rival Alemanha. De uma história que buscava caracterizar a nação e o cidadão sob rótulos de bravura e coragem. Que se encerrava no território nacional e não incorporava os intercâmbios provenientes do espaço europeu e de outros continentes. Entretanto, uma vez que toda epistemologia é essencialmente política, refletir acerca da contribuição dos Annales fora dessa ótica - tendo como justificativa que a crítica dos mesmos à história política privilegiada pela corrente metódica tornou-os imunes a uma apreciação de natureza política - é perder a possibilidade de arquitetar um exame global em torno do principal movimento historiográfico do século XX. Ou, dito de outra forma, é abrir mão da oportunidade de interpretar o século XX tal como ele foi representado pela corporação tida como a mais apta a fazê-lo. Não é a dinâmica historiográfica um dos canais mais oportunos para compreender o processo histórico em si mesmo?

\section{Marc Bloch: a história como pensamento e ação}

Bloch - que, segundo Dosse (1992), contestara a ausência de conteúdo político na revista que ele mesmo criou ${ }^{1}$ - é uma das figuras mais sintomáticas da transição histórica e epistemológica vivida pela Europa na primeira metade do século XX. Quis o destino 
que um dos principais personagens da renovação historiográfica desse período fosse ceifado exatamente por aquilo que ele havia combatido na teoria e na prática. Após a participação vitoriosa na guerra de 1914, o engajamento deliberado na Resistência (mesmo que não fosse obrigado a participar) culminaria com sua morte pelos nazistas em 1944. De certa forma, ele encarnava o passado e o futuro da Europa: de um lado, evolucionismo, belicismo, expansionismo territorial, racismo; de outro, laicismo, adesão à república, democracia e preservação do capitalismo. Sua condição de judeu só acentuaria o horror nazifascista e a via da alienação tomada pela modernidade. Talvez por isso o equilíbrio instável com Febvre, sobretudo a discordância em manter a publicação da revista sem seu nome por causa da legislação antijudaica durante a ocupação alemã. Talvez por isso tenha operado a junção passado-presente, vivificando a história e enfatizando toda sua atualidade. Talvez por isso a reflexão intelectual sobre o ofício do historiador e a preocupação cidadã em realizar um exame de consciência pertenciam a um mesmo e único processo de crítica à realidade de então.

Tal como os artigos de Braudel redigidos durante o cativeiro, a argumentação de Bloch guarda consigo a respiração angustiada do front e a situação-limite vivida em conjuntura de guerra. Todavia, se Braudel parece fazer de sua experiência como prisioneiro uma viagem "introspectiva" voltada, sobretudo, à longa duração, Bloch aproveita sua prática militar para associá-la a um passado, por assim dizer, mais imediato: o presente. Anos mais tarde, advertiria que uma dada temporalidade não autorizaria, por si só, a delimitação de um domínio científico. Ou seja, o passado não poderia ser objeto da história, assim como seria impossível uma ciência do presente em sua plenitude (BLOCH, 2006b, p. 484). Esse seria o nó górdio da história: articular as temporalidades e estabelecer suas conexões com a vida social.

Ora, esse tempo verdadeiro é, por natureza, um continuum. É também perpétua mudança. Da antítese desses dois atributos provêm os grandes problemas da pesquisa histórica. Acima de qualquer outro, aquele que questiona até a razão 
de ser de nossos trabalhos. Sejam dois períodos sucessivos, recortados na seqüência ininterrupta das eras. Em que medida - o vínculo que estabelece entre eles o fluxo da duração prevalecendo ou não sobre a dessemelhança resultante da própria duração - devemos considerar o conhecimento do mais antigo como necessário ou supérfluo para a compreensão do mais recente? (BLOCH, 2001, p. 55-56).

Eis o cerne do conhecimento histórico, inquietação de Bloch que - embora não tenha recebido atenção sistemática nem de sua parte nem de Febvre e Braudel - reflete uma série de debates da época: o passado etapista vislumbrado pelos metódicos, a denúncia do ídolo das origens de Simiand, o pensamento de Bergson em torno da duração e da memória. A "solução" passaria por dois procedimentos: a história-problema, onde o que conta não é o recorte temporal em si mas sim a questão histórica a ser formulada e respondida pelo historiador (cujos contornos, por sua vez, não podem ser estabelecidos a prior); e o ir e vir constante entre o passado e o presente, considerados não como entidades fixas mas enquanto um todo que se alimenta mutuamente. Pois se somente o estudo do passado fornecia a sensação precisa da mudança, era no presente que se encontrava a "fonte de toda a vida" (BLOCH, 2006b, p. 484).

$\mathrm{O}$ intuitivo e original Réflexions d'un historien sur les fausses nouvelles de la guerre, de 1921, sintetiza algumas das características do método annaliste, bem como abre interessantes direções de pesquisa. Bloch toma as falsas notícias de guerra não apenas como exemplo interessante de construção social em torno de uma ideia, mas também como mote para pensar a criação, divulgação e recepção do conhecimento histórico junto à sociedade. Das cartas dos soldados (quem os questionaria em plena batalha?, pergunta ele) aos relatos de jornalistas e enfermeiros, da leitura das famílias e a distribuição das informações na vizinhança, tudo se passa de forma a emprestar às falsas notícias uma racionalidade incontestável (BLOCH, 2006c).

Todavia, existe algo por trás de todo esse movimento, uma predisposição a aceitar ou aumentar aquilo que não seria mais que 
rumores. Pensemos na rivalidade envolvendo Alemanha e França após 1871. A tonalidade nacionalista propagada pelos livros didáticos de história durante boa parte da Terceira República havia favorecido a criação de um clima de discórdia e embate entre aqueles países. A sensibilidade francesa já estava propensa a considerar os alemães como inimigos "naturais". Uma informação qualquer vinda do front encontraria terreno fértil para sua proliferação e aceitação - mesmo que de forma acrítica. Algo semelhante acontecia com aqueles que estavam na frente da guerra: um soldado cansado não duvida, afirma Bloch (2006c, p. 313).

Sua formulação sobre as falsas notícias nos fornecerá mais detalhes sobre seu pensamento. Elas surgem

sempre de representações coletivas preexistentes ao seu nascimento. Seu caráter fortuito é apenas aparente ou, mais precisamente, tudo o que nela há de fortuito é seu incidente inicial, absolutamente comum, que desencadeia o trabalho do imaginário, mas esse movimento só tem lugar porque o imaginário já está preparado e surdamente fechado. Por exemplo, um acontecimento, uma má percepção que não iria senão no sentido em que todos os espíritos já estariam debruçados, poderia no máximo formar a origem de um erro individual, mas não uma falsa notícia popular e largamente difundida. Ousando servir-me de um termo que os sociólogos, a meu ver, valorizam de forma excessivamente metafísica (embora não deixe de ser cômodo e rico de sentido), a falsa notícia é o espelho onde "a consciência coletiva" contempla seus próprios traços. (BLOCH, 2006c, p. 312-313, tradução nossa).

Primeiramente, a interdisciplinaridade. O próprio esforço de definição não deixa de ser uma tentativa de fazer da história uma ciência. Definir cientificamente era uma das propostas da sociologia, disciplina com a qual Bloch mantém uma relação de aproximação e de discordância. Através de sua atração pelas mentalidades, é evidenciada também a influência da psicologia social. Em segundo lugar, o estudo das falsas notícias abria uma pista 
interessante para pensar a adesão inconsciente das massas a determinadas crenças no decorrer do processo histórico. Por exemplo: acreditar que o poder do rei provinha diretamente de Deus e que, por conta disso, seu toque teria a capacidade de curar uma doença de pele (a escrófula) - residindo, nessa trama, a manutenção do poder da nobreza (BLOCH, 1993).

Todavia, estaria Bloch pensando apenas na Idade Média ou, no fundo, tratar-se-ia de uma reflexão mais profunda sobre o perigo que a história, enquanto adesão das massas a um culto, lenda ou ideologia, poderia oferecer? Não seria esse o caso do nazismo? Uma advertência para um povo que não cultivasse a crítica histórica?

Estas últimas interrogações estão ligadas ao duplo papel assumido pela Primeira Guerra Mundial: uma crise histórica e um momento-chave na edificação de uma nova história. Nesse sentido, as falsas notícias são realmente um mote para um exame historiográfico, uma meditação sobre as origens da guerra e uma constatação do estado de crise da civilização europeia. Elas só puderam se espalhar num ambiente favorável à sua acolhida, onde a sociedade, como um todo, exprimia suas opiniões e seus julgamentos mais cruéis. Por isso, continuar admitindo que a história fosse feita somente por grandes e heroicos personagens individuais não fazia o menor sentido. Ela era muito mais ampla que os embates políticos ou nacionais, e vê-la apenas dessa forma seria simplificá-la. Contudo, o que pode parecer uma censura historiográfica é, em sua essência, uma tomada de consciência e de atitude em face do processo histórico que pesava sobre a Europa: sublinhar a dimensão social da história implicava, porém, que todos eram responsáveis por ela - e não apenas príncipes, ministros e generais. Daí a incorporação do erro, e não sua rejeição, como pregavam Langlois e Seignobos: ele não só fazia parte da história, como também revelava suas múltiplas faces (BLOCH, 2006c, p. 297-298). Daí a comparação que, ao ultrapassar fronteiras, aproximava tempos e espaços (cujas conceituações artificiais insistiam em distanciar), permitindo uma compreensão mais larga do processo histórico. 
Mesmo com a eleição de Febvre para o Collège de France em 1933 e com a chegada de Bloch à Sorbonne em 1936, passadas quatro décadas após a empreitada de Berr com a Revue de Synthèse e uma década após os Annales d'Histoire Économique et Sociale, os combates pela história não haviam cessado. Parecia importante sistematizar a démarche do historiador, aperfeiçoando e ratificando determinadas posições a fim de transmitir com clareza o "espírito" dos Annales. É assim que, dialogando com historiadores e filósofos de tradições distintas (Michelet, Coulanges, Lavisse, Langlois, Seignobos, Ranke, Febvre, Pirenne, bem como Leibniz, Montesquieu, Valéry e Bergson), além de sociólogos e economistas (Simiand e Keynes), são retomados temas como a contestação a Introduction aux études historiques; o Homem como matéria-prima da história, recusando as tentativas de fragmentá-lo e buscando reconhecê-lo na totalidade de suas ações; a problematização da história; a crítica e a ampliação dos documentos; as imbricações passado-presente; a interdisciplinaridade; a comparação.

Porém, o núcleo de Apologie pour l'histoire, ou Métier d'bistorien (escrito no início dos anos 1940 e publicado em 1949) é a defesa da história, de sua relevância social em meio a uma época conturbada e de sua relevância intelectual em face das demais ciências. Ela deveria ser preservada não como um ofício de um punhado de homens aficionados pelos depósitos de arquivos e alienados do presente, mas sim como uma ferramenta de entendimento geral da vida em sociedade e dos problemas contemporâneos. A intenção de Bloch não era outra senão retirar a história do passado, conduzi-la ao presente e, analisando essa interação, ponderar acerca das origens da tragédia europeia na primeira metade do século XX.

Não se pode negar, no entanto, que uma ciência nos parecerá sempre ter algo de incompleto se não nos ajudar, cedo ou tarde, a viver melhor. Em particular, como não experimentar com mais força esse sentimento em relação à história, ainda mais claramente predestinada, acredita-se, a trabalhar em benefício do homem na medida em que tem o próprio homem e seus atos como material? De fato, uma velha tendência, à qual atribuir-se-á pelo menos um valor 
de instinto, nos inclina a lhe pedir os meios de guiar nossa ação e, em conseqüência, a nos indignar contra ela - como o soldado vencido cuja frase eu lembrava, caso, eventualmente, pareça mostrar sua impotência em fornecê-lo. (BLOCH, 2001, p. 45).

O diálogo com a geografia também é revelador do aspecto político de sua escrita histórica (RIBEIRO, 2009a). Em termos geográficos, comparar é transpor fronteiras, aproximar lugares. É impetrar explicações cujas raízes não estão à côté: outros níveis espaciais devem ser apreciados. Circunscrever um recorte espacial não significa que ele se explique por si mesmo nem, tampouco, que seus limites não sejam cambiáveis: uma das fragilidades do conceito de região não residiria precisamente nesse aspecto? (BLOCH, 1932, p. 510). Havia que se privilegiar a geograficidade do fenômeno e não uma imposição apriorística. Casos como as estruturas agrárias da Europa não se enquadravam nas divisões políticas e administrativas formalmente estabelecidas. ${ }^{3}$ Os mapas linguísticos desse continente revelam realidades distintas das do mapa político, por exemplo (BLOCH, 2006a, p. 375).

Emblemático dessa faceta de seu pensamento é o célebre artigo Pour une bistoire comparée des sociétés européenes, de 1928 (BLOCH, 2006a). Permeado por raciocínios geográficos do início ao fim, desconfiava dos fatos exclusivamente locais na elucidação dos fenômenos e da "artificialidade" dos quadros nacionais (BLOCH, 2006a, p. 362, 380). Daí a necessidade dos estudos comparativos, "os únicos capazes de dissipar a miragem das falsas causas locais” (BLOCH, 2006a, p. 363, tradução nossa). É nesse sentido que enaltece a tese de André Meynier $A$ travers le Massif Central: Ségalas, Levézou, Châtaigneraie (1931): pela capacidade de ter sabido extrair as articulações entre a especificidade do pequeno pays e seus laços mais gerais com o movimento da França em sua totalidade. Havia uma rede social e material (os transportes) a dinamizar as trocas no Hexágono, favorecendo tanto a utilização de novas técnicas quanto o despontar de uma nova mentalidade política - a formação de sindicatos agrícolas (BLOCH, 1932, p. 496). 
Aqui, aparece com vigor uma questão que também recai no domínio da representação: a diversidade é exaltada não em nome de discursos separatistas, mas em nome do fortalecimento da coesão francesa. Eis a substância, o teor politico da argumentação desenvolvida na aproximação com a geografia na primeira metade do século XX: ${ }^{4}$ se a estética das paisagens e os gêneros de vida das regiões são retratados, por trás dessa aparente tranquilidade e de escritas tidas quase como literárias elas formavam o quadro conceitual ideal no qual seria assentada a unidade da nação francesa:

Sem dúvida, um dos méritos mais surpreendentes do sr. André Meynier foi de ter sentido e feito sentir as ligações que, entre o pequeno pays que ele examinava (de uma vida cuja aparência parecia bem particular e como que retirada) e a evolução geral da França, teceu-se uma forte e sólida rede. A influência psicológica da Grande Guerra é marcada com traços felizes. (BLOCH, 1932, p. 496, tradução nossa).

\section{Lucien Febvre: combates e defesas pela história}

Vejamos agora a dimensão política de alguns escritos de Febvre. Partiremos de uma conferência na École Normale Supérieure no ano de 1941 (isto é, após 12 anos de fundação dos Annales e em plena ocupação alemã) intitulada Vivre l'histoire. Propos d'initiation. A partir dela, adicionar-se-ão outros de seus textos em torno do debate historiográfico de então.

A história vive uma crise, embora não saiba. Tal condição não é de hoje, mas desde, pelo menos, os anos 1920, quando seus pilares ainda não estavam bem estabelecidos e fundados para o futuro (FEBVRE, 1920). Ela torna-se evidente, sobretudo, através da comparação com as demais ciências. Ciosa de sua posição institucional na academia e de seu papel social junto à nação, parece desconhecer o desenvolvimento científico dos últimos cem anos. Atada a uma concepção abstrata, hierárquica e determinista 
de mundo, insiste em "copiá-lo" tal como se fora um grande espelho a reproduzir seu reflexo mais que perfeito. Daí os cultos ao fato e ao documento, bastando a organização do primeiro em quadros rígidos e sequenciais e a catalogação do segundo em fichas e ordem alfabética para que a história estivesse pronta, acabada, imóvel.

"Atrasada frente ao último dos camponeses" (FEBVRE, 1992b, p. 23, tradução nossa), o autor parafraseia Langlois e Seignobos procurando a fórmula de uma nova história: "pas de problèmes, pas d'histoire" (FEBVRE, 1992b, p. 22). Traçando as grandes linhas da trajetória das ciências naturais, destaca o que já havia ocorrido na física, cujos campos sensoriais como a ótica, a acústica e a calorimetria foram abalados pela eletricidade, magnetismo e a eletrodinâmica de Maxwell, que modificou os conceitos de tempo, massa e longueur. No domínio da vida, o movimento deu-se por causa da microbiologia, estudando fenômenos cuja natureza escapava às leis da mecânica clássica e da geometria euclidiana. Nas ciências humanas, a geografia de Vidal e Brunhes, a psicologia de Ribot, Janet e Dumas e a sociologia de Durkheim, Mauss e Simiand renovaram expressivamente seus métodos e ponto de vista. Englobando o campo das ciências lato sensu, a revolução veio com a teoria da relatividade (e a teoria dos quanta), interrogando as noções de causalidade, determinismo, fato, lei e acaso (de modo geral, leia-se o positivismo e suas variantes) (FEBVRE, 1992b, p. 27-29).

Contudo, diferente de Simiand (1960), Febvre não proporia a adesão à démarche das ciências naturais como solução para os dilemas da história. Sua alternativa passava por reter a problematização e as hipóteses, conclamar à interdisciplinaridade e impelir a história a substituir suas prerrogativas de trabalho pelas novidades advindas do exterior. Portanto, uma nova história seria aquela que fizesse perguntas. Mais do que questionar o passado, era preciso vê-lo como um problema, como algo em construção. Isso significava inverter os termos da questão, ou seja, submeter os fatos à história e não o contrário (FEBVRE, 1992b). Se os mesmos são construídos e sujeitos à intervenção do pesquisador, tratá-los sob ângulos dessemelhantes resultaria em iluminálos cada vez mais. A interdisciplinaridade tem essa virtude: esclarecer 
Turbulência histórica e fertilidade intelectual:...

o que uma ciência, sozinha, não viu; explorar uma pista aberta pela outra; comparar resultados. Em nome da unidade social, cruzar e ultrapassar os limites dos territórios disciplinares (FEBVRE, 1992a).

Todavia, a crise da história não era apenas de cunho epistemológico, mas sim "um dos aspectos de uma grande crise do espírito humano" (FEBVRE, 1992b, p. 26-27, tradução nossa), uma consequência das mudanças de atitude dos intelectuais frente à ciência. Nas entrelinhas, emerge o colapso da própria noção de Homem erigida pela modernidade e arrasada pela eclosão do nazifascismo e pela Segunda Guerra Mundial. No fundo, a inquietação de Febvre sugere uma dupla pergunta, uma voltada para o passado e outra direcionada para o futuro.

A primeira: quais as responsabilidades da história nesse estado de coisas? As sociedades burguesas, ao materializarem o casamento entre técnica, ciência e progresso sob a bênção de uma filosofia racionalista, criaram um mundo de ilusões que não tardou a ruir. No final do século XIX, a disputa pela partilha das colônias e a organização das massas em prol de melhores condições de vida (conscientes de que a técnica e a ciência não as libertaram mas, antes, as escravizaram) desenharam o que ele classificou como "tragédia do progresso" (FEBVRE, 1992b, p. 31). Aqui emerge uma dupla faceta da reflexão febvriana: (1) o uso dos termos "sociedade burguesa", "organização das massas", "escravos", "homens livres" e mesmo a imagem do progresso enquanto tragédia (presente no Manifesto comunista e n'O capital, por exemplo) não denota outra coisa senão seu diálogo com o Marxismo, vertente incontornável no bojo da edificação de uma ciência da história; (2) os eventos dramáticos da primeira metade do século XX farão com que determinados personagens desconfiem da modernidade (ou, pelo menos, de alguns de seus traços) e sua concepção de tempo como futuro e avanço irreversíveis. É o caso dos Annales e a longue durée, do filósofo alemão Walter Benjamin (1986) e o artigo Sobre o conceito de história e do pintor espanhol Salvador Dalí com o quadro A persistência sobre a memória.

Ora, não será a longue durée e sua ênfase nas permanências e regularidades uma fundamental resposta epistemológica da nova 
geração de historiadores à modernidade capitalista? Portanto, eis Febvre associando história e historiografia, faire bistoire e faire l'histoire. O irônico é que essa réplica crítica é dissonante com a posição política dos Annales, uma revista que, além de se preocupar em circular nos meios empresariais, financeiros e políticos como ferramenta de auxílio aos problemas econômicos e sociais da atualidade, ${ }^{5}$ apoiava o colonialismo e a "missão civilizatória" francesa. ${ }^{6}$

Sim, disso não há como escapar. "Toda história é escolha" (FEBVRE, 1992a, p. 7, tradução nossa), e a de Febvre pode ser constatada no artigo que escreve por conta da exposição colonial francesa de 1931. Em nenhum momento o imperialismo é questionado. Em nenhum momento buscou-se relatar a tragédia humana, social e psicológica que se abatia sobre africanos e asiáticos. Em nenhum momento contrastou-se a exploração colonial com a pujança metropolitana. Sua inclinação política é evidenciada no momento em que ele prefere discutir a concepção de história que atravessa a exposição que o sentido da mesma. Sua impressão é a de que a exposição não foi feita pensando nos historiadores, como se eles se interessassem apenas pela poeira dos arquivos. É assim que ele reclama ter visto apenas as fotografias de generais e administradores, e não os colonos que semeiam e colhem, as massas anônimas, as pessoas que valorizam as coisas. Contesta também a ausência de stands dos grandes bancos e dos mapas de suas agências, dos gráficos e tabelas das movimentações financeiras que ele gostaria de ter observado. Afinal, apoiado sobre a "força, o trabalho e o dinheiro", estava em jogo o "esforço colonial das potências modernas" e os problemas financeiros do "grande esforço de colonização da Europa" (FEBVRE, 1932, p. 2-4, tradução nossa). Aqui, duas características dos Annales são evocadas: o deslocamento da história política - erroneamente interpretado como negligência ou desaparecimento do aspecto político na história por eles praticada - e a proeminência da história econômica e social.

De qualquer forma, a exposição não deixou de ser "agradável, harmoniosa e pitoresca, tornando-se rapidamente emocionante para quem observa e reflete" (FEBVRE, 1932, p. 7, tradução nossa). E suas impressões finais não fazem outra coisa senão 
Turbulência histórica e fertilidade intelectual:...

descortinar dois aspectos recorrentes no discurso hegemônico de então: a diminuição das diferenças materiais entre as nações e a superioridade dos europeus frente aos demais povos e raças.

Cheio de lembranças difíceis, o historiador volta à cidade meditando sobre tudo que as variações alternadas de distâncias entre raças e povos já produziram de desordem na história: se de um lado as distâncias materiais cada dia diminuem, de outro as distâncias morais permanecem constantes, enormes, talvez insuperáveis. (FEBVRE, 1932, p. 10, tradução nossa).

A "tragédia do progresso" parece ter sido esquecida por Febvre durante a exposição. Entretanto, ela trazia uma lição acerca de como ele concebia a história. Ciência crítica do passado humano? Não é o que parece, pois ele enseja conciliar os homens e seus atos, negligenciando deliberadamente a dialética marxista entre a reprodução da vida cotidiana dos trabalhadores e as desiguais condições materiais de sua existência. ${ }^{7}$ Em suas próprias palavras:

Ciência da perpétua mudança das sociedades humanas, de seu perpétuo e necessário reajustamento às novas condições de existência material, política, moral, religiosa e intelectual. Ciência do acordo que se negocia, da harmonia que se estabelece perpétua e espontaneamente, em todas as épocas, entre as condições diversas e sincrônicas de existência dos homens, condições materiais, técnicas e espirituais. (FEBVRE, 1992b, p. 31-32, grifo nosso, tradução nossa).

Enunciemos a segunda pergunta, a que fala do futuro: o que a história pode fazer para reverter tal quadro? A resposta é problematizar seu tempo (o presente) e seu ofício (o pensamento). Antes de tudo, trata-se de uma resposta historiográfica: a impressão que se tem é a de que uma mudança no processo histórico passaria, primeiramente, por uma mudança na concepção de história. Face à objetividade durkheimiana, a defesa febvriana de uma história "idealista" e sua interpretação da exposição acima 
mencionada nos dão sinais disso. No entanto, isso não quer dizer que os Annales, ao deslocarem a centralidade da história política, “baseiem sua existência na rejeição ao político”! (DOSSE, 1992, p. 64). Os exemplos são vários e fornecidos pelo próprio Dosse (!): Les rois thaumaturges, de Bloch, é, confessadamente "uma contribuição à história política da Europa, em sentido amplo, no verdadeiro sentido da palavra", e a "hipótese central de Philippe II et la Franche-Comté permanece essencialmente política" - mas, justifica ele, trata-se de uma "obra pré-Annales, antes da rejeição do aspecto político” (DOSSE, 1992, p. 92, 77)... Já outros acreditam que, por conta da tensão franco-alemã envolvendo a Universidade de Estrasburgo e a Alsácia-Lorena, os Annales se recusavam ao "engajamento político imediato" e seriam prudentes na "tomada de decisões públicas" (REIS, 2000, p. 68). A "exclusão do político" é aclarada ainda sob a ótica de que "os historiadores deviam parar de fornecer argumentos à nação (ou aos governantes), de alimentar sua necessidade de legitimidade retrospectiva e tentar dar a ela os meios de melhor compreender (e, portanto, de melhor dominar) os mecanismo da realidade social" (BURGUIÈRE, 1979, p. 1356, tradução nossa).

Voltemos às fontes? Uma passagem da conferência de abertura de Febvre do curso de história Moderna em 1920 na Universidade de Estrasburgo nos ajuda a esclarecer o papel por ele atribuído ao historiador e à sua atuação política:

Como o engenheiro, o grande industrial e o sábio técnico, o historiador deve trabalhar pela glória, grandeza e expansão de sen pais, em colaboração e em ligação constante com eles, bem como com métodos parecidos aos deles. Seguir seus progressos passo a passo, prepará-los antes, justificá-los, prolongálos pelo passado que, de antemão, determina e explica o presente - e, se ele tem algum talento, projetar no futuro a sombra dilatada e plena de promessas do presente. Tal é a sua tarefa, sua função na grande obra de restauração e expansão de seu país. E que tarefa bela e fácil no dia seguinte após a vitória, então que o prestígio do triunfo porta naturalmente a França como protagonista da cena. Que tarefa mais bela e mais urgente, sobre- 
Turbulência histórica e fertilidade intelectual:...

tudo nesta Alsácia, privada durante quase meio século de ser a portavoz do pensamento francês, cercada pelas mil mentiras e astúcias de um vencedor sem escrúpulos, tanto mais ávido a entender, enfim, a verdade francesa? A história tem serventia, e ninguém poderá dizer que a encontrou sem utilidade. (FEBVRE, 1920, p. 3-4, grifo nosso, tradução nossa).

Ora, o ambiente no qual os Annales foram formados é a prova maior de como as ideias são geradas não a partir de um plano intelectual hermético e abstrato, mas sim da dinâmica empírica do mundo em mutação. Atentemos para o emprego da palavra "ambiente": sua pretensão é a de querer relacioná-la não com o meio físico e a natureza, mas explorá-la no sentido de evocar um círculo, uma situação, um contexto que é, em sua constituição fenomênica, aquilo que seriam os Annales em termos programáticos. A Universidade de Estrasburgo viveu a situação singular de ter sido uma instituição de ensino originalmente francesa que, após a guerra de 1870-1871, foi anexada pela Alemanha. Seria preciso esperar a reconquista da Alsácia após a Primeira Guerra Mundial para que, em 1920, ela voltasse a pertencer ao Hexágono. Portanto, ao seu natural papel intelectual era acrescido o fato de que ela encarnava o orgulho francês frente à ciência alemã - além, é claro, de ocupar uma posição estratégica crucial numa região onde a geopolítica era flagrante. Em outras palavras, a universidade em tela era o retrato de um continente marcado por proporções reduzidas e grupos sociais em profusão. O resultado era uma Europa mergulhada em conflitos territoriais na esteira do processo de formação/expansão dos Estados nacionais. Estrasburgo não deixava dúvidas de que ciência e política faziam parte de uma só vocação.

Portanto, estamos diante de um projeto que é, paralelamente, político e historiográfico: ele procura renovar as bases do conhecimento sobre o passado e atuar no presente como instrumento de construção do mesmo - e não de um futuro prometido, revolucionário, inexequível. Não é um retorno a um passado mítico e criador de grandes heróis, mas um compromisso com a renovação do conhecimento histórico cuja vontade de potência é contribuir para 
a pujança do Império Francês, para a reconstrução da nação após o trauma da ocupação alemã e para a paz europeia (RIBEIRO, 2009b). Tal como a noção de teoria não advém mais dos grandes sistemas filosóficos, a noção de política que atravessa as ciências sociais não é mais a mesma de outrora, cristalizada no EstadoNação. São savants que não se abstinham de pensar a situação de seus países inserindo-os no plano internacional e não encerrados em seus próprios territórios. Raciocinar a política através da ciência, mas sem a obrigação de fazê-lo. Servir como fonte de saber autônomo e tomada de consciência crítica frente aos desafios do mundo moderno. Uma história nova poderia auxiliar na construção de um mundo novo. Seria essa uma nova etapa da herança iluminista? Pode ser, mas sem componentes metafísicos, utopias utilitaristas ou ambições filosóficas. Ou seja, com ressalvas. Os herdeiros desconfiavam de sua própria herança. O momento agora era outro: pregava-se a cooperação interdisciplinar, o diálogo aberto com a sociedade, os intercâmbios científicos, as explicações multicausais.

A pergunta a se fazer é: como desconhecer o caráter político dessa concepção de história? Analisar um discurso significa tanto reconhecer aquilo que ele explicita quanto o que rejeita, e é exatamente nesse jogo de inclusão e exclusão que sua trama com o poder se manifesta. Deslocar a história das batalhas, dos militares e da diplomacia em nome da dimensão econômico-social não significa, em hipótese alguma, o desaparecimento de seus vínculos políticos, sobretudo quando emprestamos a esse termo a noção de interesse. Quais são os interesses dos Annales? Efetuar tal deslocamento na medida em que pressentiram que a política e o poder estariam nas mãos do mercado e, assim, situar a história numa posição privilegiada frente às demais ciências humanas? Auxiliar o mundo dos negócios com análises históricas a fim de evitar ou compreender com mais clareza o mecanismo das crises econômicas? Desenvolver uma concepção de tempo apoiada não só no sincronismo e na mudança, mas também no diacronismo e na permanência e, com isso, minimizar as alternativas históricas que propunham alterações revolucionárias na vida social? Insistir na historicidade como elemento nuclear para o estudo dos fenômenos 
humanos e, com isso, reunir as ciências sociais sob sua égide? Independentemente da resposta estar contida nesses enunciados, o que parece difícil alegar é que os Annales possuíam "uma orientação sem expressão política", visto que "não pretendiam influenciar nenhum partido nem aconselhar príncipe algum" (BURGUIÈRE, 1979, p. 1357, tradução nossa). O próprio fato de que Bloch e Febvre cuidassem para que o historiador não julgasse a história em termos valorativos (BLOCH, 2006b, p. 477), pois ela não era advocacia (FEBVRE, 1920, p. 5), mostra uma tentativa malograda de neutralidade, posto que não condizia nem com a posição colonialistacapitalista de ambos nem com a defesa de que o cientista intervinha diretamente sobre seu objeto de pesquisa, interrogando-o e delimitando-o. Ora, visto dessa forma, o problema não parecia ser a história, mas sim o historiador!

\section{Conclusão}

A originalidade historiográfica praticada por Bloch e Febvre consiste não apenas na capacidade de mesclar conhecimentos variados, mas sobretudo em articulá-los segundo a linguagem histórica da longa duração. Incide na sensibilidade ao captar que determinadas mudanças históricas processadas na primeira metade do século XX (Revolução Russa, Primeira Guerra Mundial, nazifascismo e Crise de 29) afetaram a tradicional concepção de tempo. No entendimento que a multiplicidade dos fenômenos humanos possui ritmos distintos e inter-relacionados, tornando a historicidade uma noção ligada à mudança e à permanência. Na compreensão de que o passado está propenso à mudança graças às novidades empíricas e teóricas geradas pelo presente que, por sua vez, guarda consigo as heranças daquele. Sua fugacidade só se torna inteligível nessa condição (em outras palavras, o presente conserva o passado e, simultaneamente, o renova). No imperativo de abrir a história aos aportes oferecidos pela economia, arqueologia, geografia, sociologia, linguística e psicologia e, paralelamente, submetê-los ao ponto de vista histórico. $\mathrm{Na}$ consciência da unidade profunda e indissociável da vida humana, combatendo as visões fragmentárias e o espírito 
de especialização. Na convicção de que a vida social é uma rede de relações e um complexo de significações inconciliáveis com explicações monocausais e deterministas. $\mathrm{Na}$ ampliação do conceito de fonte/documento, vislumbrando como matéria-prima do historiador todo e qualquer tipo de traço deixado pelo homem (mapas, pinturas, esculturas, peças de teatro, vasos, paisagem...). Tudo isso atravessado pela dimensão política. A saber: o comprometimento com o colonialismo, o fortalecimento do Estado e suas fronteiras territoriais e o engajamento em defesa da ciência histórica à luz da longa duração.

\section{Historical turbulence and intelectual fertility: a political reading from Marc Bloch and Lucien Febvre historiography}

Abstract: The aim of this article is recognize the politics dimension in Marc Bloch and Lucien Febvre's historiography. Since that they dislocated the Politics History and emphasized the Economic and Social History, his works have been interpretated as it did not cover policy issues. This text wants to interrogate this approach.

Keywords: History. Historiography. Politics. Marc Bloch. Lucien Febvre.

\section{Notas}

${ }^{1}$ De L'étrange défaite "sobressai certa autocrítica das posições do grupo dos Annales: 'Nós temos, na maioria, o direito de dizer que fomos bons operários, fomos sempre bons cidadãos?' [Bloch] Questiona, nesse momento, o fatalismo do discurso dos Annales que, ao privilegiar o jogo de forças maciças e negar o papel dos indivíduos e dos engajamentos, acaba se afastando da ação tanto individual quanto coletiva." (DOSSE, 1992, p. 64).

2 "A guerra, o disse mais acima, foi uma imensa experiência de psicologia social. Consolar-se de seus horrores alegrando-se de seu interesse experimental seria fingir um diletantismo de mau tom. Mas, uma vez que ela teve lugar, convém empregar seus ensinamentos para o melhor de nossa ciência." (BLOCH, 2006c, p. 316, tradução nossa).

3 “Tais são alguns dos principais problemas da paisagem rural francesa. Melhor dizendo: europeia. Cercas, campos irregulares, campos alongados, agricultura individual ou servidão coletiva. Com efeito, tantas realidades que se reencontram e se opõem para além de nossas fronteiras. E, sem dúvida, lá como aqui, o meio mais 
seguro de compreender a França é, algumas vezes, sair dela." (BLOCH, 1936, p. 273, tradução nossa).

${ }^{4}$ Uma análise detalhada sobre as relações entre geografia, política e os escritos de Bloch, Febvre e principalmente Braudel foi operada por Ribeiro (2008).

${ }^{5} \mathrm{~A}$ adesão ao capitalismo e a tendência tecnocrata dos Annales são objeto de rechaço por parte de Dosse (1992, p. 69), para quem "os dois diretores dos Annales reivindicam, ainda mais, o elo orgânico entre passado e presente, ao qual aderem com uma lógica gerencial do sistema capitalista. Contam adaptar sua abordagem histórica à era técnica, na qual esperam desempenhar papel útil. É nesse espírito que eles se rodeiam dos responsáveis tanto do meio administrativo quanto do mundo dos negócios. A revista atrai os especialistas cuja tarefa essencial é agir sobre os aspectos econômicos e sociais." Por sua vez, Burguière (1979, p. 1353, tradução nossa) revela que "experts internacionais (como Mequet) e especialistas vindos do mundo bancário (como Houdaille) colaboram regularmente na revista durante esse período. [...] Em 1931, Marc Bloch apresenta um artigo de N. S. B. Grass, professor da Harvard Business School, insistindo no fato que os homens de negócios e de ação tinham necessidade da história não para tomar exemplos ou casos precedentes, mas para levar em consideração os mecanismos de mudança."

${ }^{6}$ Interpretação semelhante à nossa é feita por Paligot (2009), atentando para o silêncio da revista em face de escritos críticos do colonialismo - como Voyage au Congo, de Gide, por exemplo - e para o engajamento de Febvre e Braudel na empreitada colonial. Daí nossa surpresa ao constatar que Paris (1999, p. 221, tradução nossa) faz uma avaliação totalmente oposta, expressa da seguinte forma: "Contra o fascismo e o racismo, os Annales querem erigir a barreira de um humanismo colonial sob dois planos: acelerar o aprofundamento de uma colonização justa, fundada sobre uma troca igual dos bens e o alargamento do horizonte intelectual, bem como descartar, de uma vez por todas, o velho espírito nacionalista conquistador. Era chegado o período em que todo homem, independentemente da cor de pele, fosse reconhecido e respeitado em sua dignidade. Sob a pena de Febvre, esta seria a empresa ideal da colonização europeia: uma solidariedade feita de benevolência, onde aquela coexistiria com o progresso e os princípios democráticos. Essa proposição tem o mérito de nos lembrar os desafios intelectuais e políticos da descolonização na França e sobre quais termos os debates se colocam, numa época onde as reivindicações políticas que começavam a se exprimir na Argélia falavam de assimilação (ou seja, sobre a igualdade de direitos entre argelinos e franceses) e não de independência."

${ }^{7}$ Socialista na juventude, mais tarde Febvre (1920, p. 8-13) manifestaria seu desacordo com o marxismo: a despeito de suas "notáveis deduções", o Manifesto era, para ele, uma síntese histórica por demais ambiciosa, fechada, unitária, onde a burguesia era algo "in abstracto" e o conceito de classe e o materialismo como um 


\section{Guilherme Ribeiro}

todo eram economicistas. Nas entrelinhas, estaria ele reprovando igualmente a Revolução Russa? De qualquer forma, a relação entre os Annales e o marxismo permanece pouco (e mal) explorada. Para Stoianovich (1976 apud DOSSE, 1992, p. 65), a historiografia marxista é, simultaneamente, precursora e rival dos Annales. Para Dosse (1992, p. 69), a participação de banqueiros e financistas na revista "torna desprezível a análise segundo a qual a mesma seria a expressão de um discurso marxista". Historiadores marxistas britânicos mostraram divergências a respeito: enquanto Hobsbawm (1998, p. 193-194, 2002) mostra certa simpatia para com os Annales, Thompson ([s.d.], p. 311) ressaltava o conservadorismo deles e suas insistências nas formações de longa duração, embora aceitasse certa estreiteza entre as tradições inglesa e francesa. Peter Burke (1997, p. 113) retrata que Hilton e Hobsbawm estavam entre os primeiros a saudar os Annales na Inglaterra, atitude explicada pelo fato de que aqueles os viam num somatório de forças contra a história política tradicional. Outros ângulos da questão podem ser consultados (BOIS, 1990; CARDOSO, 1999; KAYE, 1989; LE GOFF, 1990; STEDMAN JONES, 1998; VILAR, 1976). Todavia, a reflexão de Aguirre Rojas (2000, p. 25-177) se destaca como a mais pormenorizada em torno do tema.

\section{Referências}

AGUIRRE ROJAS, C. A. Os Anales e a historigrafia francesa: tradições críticas de Bloch e Foucault (1921-2001). Maringá: Eduem, 2000.

AGULHON, M. La République I (1880-1932). Paris: Hachette, 1990.

BENJAMIN, W. Sobre o conceito de história. In: BENJAMIN, W. Obras escolbidas: magia e técnica, arte e política. 2. ed. São Paulo: Brasiliense, 1986. p. 222-232.

BLOCH, M. Régions naturelles et groupes sociaux. Annales d'bistoire économique et sociale, v. 4, n. 17, p. 489-510, 1932.

Les paysages agraires: essais de mise au point. Annales d'bistoire économique et sociale, n. 39, p. 256-277, 1936.

. Os reis taumaturgos. São Paulo: Companhia das Letras, 1993.

2001. - Apologia da bistória on o oficio de bistoriador. Rio de Janeiro: Jorge Zahar,

. Pour une histoire comparée des sociétés européenes. In: BLOCH, M.

L'Histoire, la Guerre, la Résistance. Paris: Gallimard, 2006a. p. 347-380. 
. Qui demander à l'Histoire? In: BLOCH, M. L'Histoire, la Guerre, la Résistance. Paris: Gallimard, 2006b. p. 467-484. Réflexions d'un historien sur les fausses nouvelles de la guerre. In: BLOCH, M. L'Histoire, la Guerre, la Résistance. Paris: Gallimard, 2006c. p. 293-316.

BOIS, G. Marxismo e História Nova. In: LE GOFF, J. (Org.). A História Nova. São Paulo: Martins Fontes, 1990. p. 242-260.

BOURDÉ, G.; MARTIN, H. L'école méthodique. In:BOURDÉ, G.; MARTIN, H. Les écoles historiques. Paris: Seuil, 1997. p. 181-214.

BURGUIÈRE, A. Histoire d'une histoire: la naissance des Annales. Annales ESC, n. 6, p. 1347-1359, nov./déc. 1979.

BURKE, P. A Escola dos Annales (1929-1989): a Revolução Francesa da historiografia. São Paulo: Unesp, 1997.

CAIRE-JABINET, M.-P. Introdução à historiografia. Bauru: Edusc, 2003.

CARDOSO, C. F. História e paradigmas rivais. In: CARDOSO, C. F.; VAINFAS, R. (Org.). Dominios da história: ensaios de teoria e metodologia. Rio de Janeiro: Campus, 1999. p. 1-23.

DOSSE, F. A história em migalhas: dos “Annales” à Nova História. Campinas: Editora da Unicamp; Ensaio, 1992.

FEBVRE, L. L'histoire dans un monde en ruines. Revue de Synthèse Historique, n. 88, p. 1-15, fév. 1920.

. L'histoire économique et la vie: leçon d'une exposition. Annales HES, n. 4, p. 1-10, 1932.

. De 1892 à 1933. Examen de conscience d'une histoire et d'un historien. In: FEBVRE, L. Combats pour l'bistoire. Paris: Armand Colin, 1992a. p. 3-17.

.Vivre l'histoire. Propos d'initiation. In: FEBVRE, L. Combats pour l'histoire. Paris: Armand Colin, 1992b. p. 18-33.

FONTANA, J. História dos homens. Bauru: Edusc, 2004.

GURIÊVITCH, A. A sintese histórica e a Escola dos Anais. São Paulo: Perspectiva, 2003.

HOBSBAWM, E. Era dos extremos: o breve século XX: 1914-1991. São Paulo: Paz e Terra, 1995. . Sobre história. São Paulo: Companhia das Letras, 1998. 


\section{Guilherme Ribeiro}

Tempos interessantes: uma vida no século XXI. São Paulo: Companhia das

Letras, 2002.

KAYE, H. J. Los historiadores marxistas británicos. Zaragoza: Prensas Universitarias, 1989.

LE GOFF, J. A história nova. In: LE GOFF, J. (Org.). A História Nova. São Paulo: Martins Fontes, 1990. p. 125-152.

NOIRIEL, G. Sur la crise de l'histoire. Paris: Gallimard, 2005.

PALIGOT, C. R. Les Annales de Lucien Febvre à Fernand Braudel: entre épopée coloniale et opposition Orient/Occident. French Historical Studies, v. 32, n. 1, p. 121 144, Winter, 2009.

PARIS, E. La genèse intellectuelle de l'oeuvre de Fernand Braudel. Athènes: Institute de Recherches Néohelléniques/FNRS, 1999.

POMIAN, K. L'heure des Annales. In: NORA, P. (Dir.). Les lieux de mémoire: In: la République: la Nation. les France. Paris: Gallimard, 1997. p. 903-952.

REIS, J. C. Escola dos Annales: a inovação em história. Rio de Janeiro: Paz e Terra, 2000.

REVEL, J. Histoire et Sciences Sociales. Les paradigmes des Annales. Annales ESC, n. 6, p. 1360-1376, nov./déc. 1979.

RIBEIRO, G. Espaço, tempo e epistemologia no século XX: a geografia na obra de Fernand Braudel. Tese (Doutorado em Geografia) - Instituto de Geociências, Universidade Federal Fluminense, Niterói, 2008.

- A geografia testemunha a história: paisagem, região e interdisciplinaridade em Marc Bloch. Revista de História Regional, v. 14, n. 2, p.7-28, 2009 a.

. Para ler geografia ou A geografia segundo Lucien Febvre. Terra Livre, n. 32, p. 121-145, 2009b.

SIMIAND, F. Méthode historique et science sociale. Annales HSS, v. 15, n. 1, p. 83 119, 1960.

STEDMAN JONES, G. Historiographie française, historiographie anglaise. Une autre histoire sociale? (note critique). Annales HSS, n. 2, p. 383-394, mars/avril 1998.

THOMPSON, E. Una entrevista com E. P. Thompson. In: THOMPSON, E. Tradición, revuelta y consciencia de clase. Barcelona: Editorial Crítica, [s.d.]. p. 294-318. 
Turbulência histórica e fertilidade intelectual:...

VILAR, P. História marxista, história em construção. In: NORA, P., LE GOFF, J. (Org.). História: novos problemas. Rio de Janeiro: Francisco Alves, 1976. p. 146178.

Recebido em: 19/02/2010

Aprovado em: 14/05/2010

Anos 90, Porto Alegre, v. 17, n. 31, p. 233-260, jul. 2010 